\title{
Risk Factors of Ovarian Cancer in PKU Muhammadiyah Teaching Hospital Yogyakarta
}

\author{
Supriyatiningsih ${ }^{1,2}$, Alfun Dhiya $\mathrm{AN}^{1}$, Witri Andi Pratiwi ${ }^{1}$, Ralph J. Lelle ${ }^{2}$, Joerg Haier ${ }^{3}$ \\ ${ }^{1}$ Obstetrics and Gynecology Department, Faculty of Medicine and Health Sciences, Universitas Muhammadiyah \\ Yogyakarta. Jl Brawijaya, Tamantirto, Kasihan, Bantul, Yogyakarta, Indonesia \\ ${ }^{2}$ Geburtshilfe und Frauenheilkunde, Universitatklinikum Muenster/Westfaliche Wilhelms-University of Muenster, \\ Germany \\ ${ }^{3}$ Comprehensive Cancer Centre, Hannover Medical School, Germany
}

DATA OF ARTICLE:

Received: 05 Feb 2020

Reviewed: 20 Mar 2020

Revised: 18 May 2020

Accepted: 20 Jun 2020

\section{*CORRESPONDENCE:}

supriyatiningsih.wenang@uni-

muenster.de

DOI:

10.18196/mm.200247

TYPE OF ARTICLE:

Research

\begin{abstract}
In PKU Muhammadiyah Teaching Hospital Yogyakarta from 2014 to 2017, ovarian cancer is 5th out of all types cancers diagnosed. Recognition and identification of ovarian cancer risk factors are very important to prevent the patient both from morbidity and mortality. The purpose of this study was to estimate the relationship between low parity, infertility, age, and family history with ovarian cancer in this hospital. This study was an observational analytical study with case control design. The sample was medical record of 74 women with ovarian cancer and non ovarian cancer the hospital period April 2014 to September 2017 with inclusion and exclusion criteria. Data analysis used chisquare test. The bivariat analysis showed that there is no relationship between low parity with ovarian cancer $(\mathrm{p}=0.790 \mathrm{OR}=0.87 ; 95 \% \mathrm{CI} 0.305-2.466)$, there is no relation between infertility with ovarian cancer $(\mathrm{p}=0.104 \mathrm{OR}=2.48$; $95 \% \mathrm{CI}$ $0.815-7.545)$, and there is no relation between family history with ovarian cancer $(\mathrm{p}=0.304 \mathrm{OR}=3.18 ; 95 \% \mathrm{CI} 0.315-32.039)$. But there is a relationship between age with ovarian cancer $(\mathrm{p}=0.01 \mathrm{OR}=0.11 ; 95 \% \mathrm{CI} 0.022-0,510)$. Age is a risk factor of ovarian cancer, while there is no relation between low parity, infertility, and family history with ovarian cancer.
\end{abstract}

Keywords: Risk Factors, Ovarian Cancer, Age.

\begin{abstract}
Abstrak: Di RS Pendidikan PKU Muhammadiyah Yogyakarta 2014-2017, kanker ovarium menempati urutan ke-5 dari semua jenis kanker yang terdiagnosis. Pengenalan dan identifikasi faktor risiko kanker ovarium sangat penting dilakukan untuk mencegah penderita baik dari morbiditas maupun mortalitas. Tujuan penelitian ini adalah untuk mengetahui hubungan paritas rendah, infertilitas, umur, dan riwayat keluarga dengan kanker ovarium di RS ini. Penelitian ini merupakan penelitian analitik observasional dengan desain case control. Sampel adalah rekam medis 74 wanita penderita kanker ovarium dan kanker non ovarium di RS tersebut periode April 2014 sampai September 2017 dengan kriteria inklusi dan eksklusi. Analisis data menggunakan uji chi-square. Analisis bivariat menunjukkan bahwa tidak ada hubungan antara paritas rendah dengan kanker ovarium ( $p=0.790 \mathrm{OR}=0.87$; CI 95\% 0.305-2.466), tidak ada hubungan antara infertilitas dengan kanker ovarium $(p=0.104 \mathrm{OR}=2.48 ; 95 \% \mathrm{CI}$ $0.815-7.545)$, dan tidak ada hubungan antara riwayat keluarga dengan kanker ovarium $(p=0.304 \mathrm{OR}=3.18 ; 95 \% \mathrm{CI}$ 0.315-32.039). Tetapi ada hubungan antara umur dengan kanker ovarium ( $p=0.01 \mathrm{OR}=0.11 ; 95 \% \mathrm{CI} 0.022-0.510)$. Usia merupakan faktor risiko terjadinya kanker ovarium, sedangkan paritas rendah, infertilitas, dan riwayat keluarga tidak ada hubungan dengan kanker ovarium.
\end{abstract}

Kata Kunci: Faktor Risiko, Kanker Ovarium, Usia.

\section{INTRODUCTION}

Cancer is an abnormal cell growth. Cancer is formed by an organ or body structure consisting of small cells that will grow up into mass, because the cells have lost the ability to stop growing. ${ }^{1}$ Cancer is a major cause of mortality worldwide. By 
2015, cancer causes 8.8 million deaths. The most common cancer causes deaths: lung cancer (1.69 million deaths), liver cancer (788,000 deaths), colorectal cancer (774,000 deaths), stomach cancer (754,000 deaths), and breast cancer $(571,000){ }^{2}$

In Indonesia, the prevalence of patient with cancer at all ages is $1.4 \%$. Yogyakarta province is the province with the highest prevalence of cancer $4.86 \%$, which is much higher than the national rate. ${ }^{3}$ The next highest prevalence is in Central Java province of $2.1 \%$ and Bali province of $2.0 \% .4$

A report from Dharmais Cancer Hospital 2010-2013 showed that breast cancer, cervical cancer, lung cancer, ovarian cancer, rectal cancer, thyroid cancer, colon cancer, hepatoma and nasopharyngeal cancer are the most common cancer in Dharmais Hospital for four consecutive years. There was also an increase of ovarian cancer incidence reported as many as 113 new cases from a total of 1722 new cases in 2010 (6.56\%). ${ }^{4}$ The indicates that ovarian cancer is ranked $4^{\text {th }}$ after breast cancer, cervical cancer, and lung cancer in the United States. ${ }^{5}$

Ovarian cancer is the fifth leading cause of death from all types of cancers present in the female reproductive system. In the United States, by 2017 an estimated 22,440 women will be diagnosed with ovarian cancer and 14,080 women will die from ovarian cancer. ${ }^{2,6}$

Medical record data of PKU Muhammadiyah Teaching Hospital Yogyakarta period 2014 to 2017 showed that ovarian cancer is the fifth highest among all diagnosed cancers. In addition, ovarian cancer is also ranked second highest after breast cancer of all types of cancer in the female reproductive system.

Ovarian cancer is one of the malignant diseases found in female reproductive organs, which can originate in germ cells, epithelial or granulosa cell cells, but almost always from epithelial cells. Ovarian cancer results from the growth of abnormal cells in one or both parts of the ovary. ${ }^{6,7}$

Ovarian cancer is associated with low parity and infertility. Although it may be related to other factors, such as the use of talc, the consumption of galactose, and tubal ligation, but which is strongly associated with the incidence of ovarian cancer is the history of reproduction and the duration of the history of reproductive work. Early menarche and late menopause increase the risk of ovarian cancer. The risk of ovarian cancer is strongly associated with family history, especially ovarian cancer from epithelial cells accounting for $5 \%$ to $10 \%$ including malignant.?
Ovarian cancer usually does not have a symptom at an early stage, so the patient is usually diagnosed when the cancer was metastasised. ${ }^{8}$ Ovarian cancer that found in the early stages is only about $20 \%$. Approximately $94 \%$ of patients can survive more than 5 years after diagnosis, when ovarian cancer is diagnosed at an early stage. ${ }^{9}$

From the data above, the prevalence of ovarian cancer in Indonesia is still very high. Ovarian cancer is generally without any early-stage symptoms makes most ovarian cancers diagnosed after metastasis. Of these phenomena, it requires preventive and promotive efforts in reducing the incidence of ovarian cancer, one of which identifies the risk factors of ovarian cancer. This is what makes researchers interested in conducting research to identify most common risk factors in our teaching hospital.

\section{MATERIALS AND METHOD}

A case control design was employed in the study that include a total 37 patients with ovarian cancer and 37 patients with non-ovarian cancer for control group. In this study, the data were collected from medical record data both ovarian and non ovarian cancer patients in the Hospital of study period of April 2014 to September 2017 which has met the inclusion criteria and exclusion criteria. The inclusion criteria includes women with ovarian cancer and non ovarian cancer, and there are free variable data to be studied. While women with ovarian cancer with complications excluded from this study. The study has been approved by the Ethical Research Committee of the affiliated institution of the first author.

Statistical Package for the Social Sciences (SPSS) was used to test the data. Univariate analysis was conducted to investigate the characteristics of respondents and Chi-square was employed to measure the relation between variabel.

\section{RESULT}

Data number of parities, infertility, age, and family history was collected and are shown in Table 1. Table 1 shows number of parities. Most of the samples have parity $\leq 2(n=55,74.3 \%)$. and samples having parity> 2 were 19 people (25.7\%). More than $75 \%$ samples were non infertile.

Based on age, the number of samples with age $\leq 40$ years were 15 persons (20.3\%) and samples with age $>40$ years were 59 people (79.7\%). This indicates that the sample in this study was dominated by a sample with age $>40$ years. This study indicates that the samples in both groups 
were dominated by samples with no family history of cancer ( $n=70$ people, $94.6 \%$ ).

There is no significant relation between ovarian cancer with low parity as shown in Table 2. Since there is no meaningful relationship, the value of OR does not give the relationship meaning accurately or real. The OR score was 0.87 (1 / $0.87=$ 1.15) with the meaning of women with $>2$ parities having 1.15 times higher incidence of ovarian cancer than women with low parity $\leq 2$.

Table 3 shows that ovarian cancer is not significantly related with infertility. Since there is no meaningful relationship, the value of OR does not give the relationship meaning accurately or real. Obtained an OR value of 2.48 with the meaning of women with infertility has a 2.48 times higher incidence of ovarian cancer than women who did not experience infertility.

From Table 4 it can see that there is a significant relationship between ovarian cancer and age $(p=0.01)$. Obtained an OR value of $0.11(1 / 0.11=$ $9.09)$, meaning that women aged $>40$ years have 9.09 times higher chance of ovarian cancer than women aged $\leq 40$.

Table 5 shows no significant relationship between ovarian cancer and family history. Because there is no meaningful relationship, the OR does not provide an accurate or real meaning of the relationship. Obtained an OR value of 3.18 which means that women who have a family history of cancer have 3.18 times higher chance of ovarian cancer than women who have no family history of cancer.

Table 1. Distribution of Samples

\begin{tabular}{cccc}
\hline No & Variable & Amount & Percentage \\
\hline \multirow{4}{*}{1} & Total Parity & & \\
& $\leq 2$ & 55 & $74.3 \%$ \\
& $>2$ & 19 & $25.7 \%$ \\
2 & Infertility & & \\
& Yes & 18 & $24.3 \%$ \\
& Not & 56 & $75.7 \%$ \\
3 & Age & & \\
& $\leq 40$ years old & 15 & $20.3 \%$ \\
& $>40$ years old & 59 & $79.7 \%$ \\
4 & Family History & & \\
& Yes & 4 & $5.4 \%$ \\
& Not & 70 & $94.6 \%$ \\
\hline
\end{tabular}

Table 2. Low Parity Relationship with The Incidence of Ovarian Cancer

\begin{tabular}{|c|c|c|c|c|c|}
\hline \multirow{2}{*}{$\begin{array}{c}\text { Parity } \\
\text { Low }\end{array}$} & \multicolumn{2}{|c|}{ Ovarian Cancer } & \multirow{2}{*}{ OR } & \multirow{2}{*}{$\mathrm{Cl}(95 \%)$} & \multirow{2}{*}{$\mathbf{P}$} \\
\hline & Yes & Not & & & \\
\hline$\leq 2$ & 27 & 28 & \multirow{2}{*}{0.87} & \multirow{2}{*}{$0.305-2.466$} & \multirow{2}{*}{0.790} \\
\hline$>2$ & 10 & 9 & & & \\
\hline
\end{tabular}

Table 3. Relationship of Infertility with The Incidence of Ovarian Cancer

\begin{tabular}{|c|c|c|c|c|c|}
\hline \multirow{3}{*}{ Infertility } & \multirow{2}{*}{\multicolumn{2}{|c|}{$\begin{array}{l}\text { Ovarian } \\
\text { Cancer }\end{array}$}} & \multirow{3}{*}{ OR } & \multirow{3}{*}{$\mathrm{Cl}(95 \%)$} & \multirow{3}{*}{$\mathbf{P}$} \\
\hline & & & & & \\
\hline & Yes & Not & & & \\
\hline Yes & 12 & 6 & \multirow{2}{*}{2.48} & \multirow{2}{*}{$0.815-7.545$} & \multirow{2}{*}{0.104} \\
\hline Not & 25 & 31 & & & \\
\hline
\end{tabular}

Table 4. Relationship between Age and Incidence of Ovarian Cancer

\begin{tabular}{|c|c|c|c|c|c|}
\hline \multirow[t]{2}{*}{ Age } & \multicolumn{2}{|c|}{$\begin{array}{l}\text { Ovarian } \\
\text { Cancer }\end{array}$} & \multirow[t]{2}{*}{ OR } & \multirow[t]{2}{*}{$\mathrm{Cl}(95 \%)$} & \multirow[t]{2}{*}{$\mathbf{P}$} \\
\hline & Yes & Not & & & \\
\hline $\begin{array}{c}\leq 40 \text { years } \\
\text { old }\end{array}$ & 2 & 13 & & & \\
\hline $\begin{array}{l}>40 \text { years } \\
\text { old }\end{array}$ & 35 & 24 & 0.11 & $0.022-0.510$ & 0.01 \\
\hline
\end{tabular}

Table 5. Relationship of Family History with The Incidence of Ovarian Cancer

\begin{tabular}{cccccc}
\hline \multirow{2}{*}{$\begin{array}{c}\text { Family } \\
\text { History }\end{array}$} & \multicolumn{2}{c}{$\begin{array}{c}\text { Ovarian } \\
\text { Cancer }\end{array}$} & \multirow{2}{*}{ OR } & Cl(95\%) & P \\
\cline { 2 - 3 } & Yes & Not & & & \\
\hline Yes & 3 & 1 & \multirow{2}{*}{3.18} & $\begin{array}{c}0.315- \\
32.039\end{array}$ & 0.304 \\
\hline Not & 34 & 36 & & 32.039 \\
\hline
\end{tabular}

\section{DISCUSSION}

The statistical results of the bivariate analysis in table 2 show that there is no significant relationship between low parity and the incidence of ovarian cancer. In addition, women who have parity> 2 have 1.15 times higher chance of growing ovarian cancer than women who have low parity $\leq 2$. This is in line with the results of research at RSUD Dr. H. Abdul Moeloek Bandar Lampung in 2015-2016 which shows that there is no relationship between the number of parity and the degree of histopathology of ovarian cancer. ${ }^{10}$ Such condition can be caused chronic irritation in the ovaries of nonpregnant women due to repeated ovulation processes. ${ }^{11}$ In addition, the theory of incessant ovulation explains that ovulation every month can cause damage to the fallopian and ovarian tissue, so that when ovulation does not occur (anovulation) in pregnancy can have a protective effect. ${ }^{12}$

The statistical results of the bivariate analysis in table 3 show that there is no significant relationship between infertility and the incidence of ovarian cancer. Women with infertility are 2.48 times more likely occurrence of ovarian cancer than women who do not experience infertility. Previous studies found various finding. For example, the current study is in line with findings from previous study. ${ }^{14}$ However, the current findings was contrary with findings from two studies. ${ }^{13}$ This can be explained by the theory of increased gonadotropin hypothesis which shows that an increase in the 
hormone gonadotropin can cause proliferation and transformation of epithelial cells into malignant. ${ }^{13}$

The current study found a significant relationship between age and the incidence of ovarian cancer. Women who are $>40$ years old are 9.09 times more likely to develop ovarian cancer than women who are $\leq 40$ years old. This is in line with the results of research at Prof. RSUP Dr. RD. Kandou Manado period January 2013 - December 2015 which showed that ovarian cancer occurs most often in women with age $\geq 51$ years. ${ }^{15}$ These results are also supported by the results of previous studies which showed that most epithelial ovarian cancer sufferers were among women> 50 years of age. ${ }^{16}$ This happens because of increasing age in women can cause genetic changes in epithelial cells on the surface of the ovaries..$^{12}$ But the results were not in line with the results of a study at the Abdoel Moelok Regional General Hospital, Lampung Province in 2015 which stated that there was no relationship between age and the incidence of ovarian cancer. This difference is possible due to differences in age groupings in the study. ${ }^{17}$

The incidence of ovarian cancer is not significantly related with family history as found in the current study. Further, it was found that women who have a family history of cancer are 3.18 times more likely to develop ovarian cancer than women who have no family history of cancer. These results are in line with the results of research at the Abdoel Moelok Regional General Hospital, Lampung Province in 2015 which showed that there was no relationship between family history of cancer and the incidence of ovarian cancer. ${ }^{17}$ The current finding is also supported by previous study conducted at Dr. Soetomo Hospital in the period March-April 2016 found that 79\% of ovarian cancer sufferers had no family history of cancer. ${ }^{16}$ However this is not in line with the results of previous studies which found that there was a strong relationship between family history and the incidence of ovarian cancer. ${ }^{11}$ Serous ovarian cancer is associated with mutations in the BRCA1 gene and the $B R C A 2^{18}$ gene.

In this study there are some weaknesses that occur due to incomplete medical record data of ovarian cancer patients and patients who do not suffer from ovarian cancer, especially those related to the independent variables studied such as the amount of parity, whether or not infertility, age, and family history of the patient. This affects the inclusion and exclusion criteria of this study. In addition, this also results in a reduced number of samples due to the lack of necessary data.

\section{CONCLUSION}

It can be concluded that there is a significant relationship between age and the incidence of ovarian cancer. Other factors such as low parity, infertility, and family history were not significantly related with the incidence of ovarian cancer

\section{Conflicts of interest}

No conflicts of interest have been declared by the authors.

\section{Acknowledgement}

This research conducted by collaboration between Department Obstetrics and Gynecology Faculty of Medicine and Health Sciences, Universitas Muhammadiyah Yogyakarta/PKU Muhammadiyah Teaching Hospital Yogyakarta, Indonesia, University hospital of Muenster/Westfaliche Wilhelms University, Germany and Comprehensive Cancer Centre, Hannover Medical School, Germany.

\section{REFERENCES}

1. Sekeres MA, Stern TA. Facing Cancer: A Complete Guide For People With Cancer, Their Families, and Caregivers. United States: McGraw-Hill. 2004

2. World Health Organization. 2017. Cancer. URL:https://www.who.int/health-

topics/cancer\#tab=tab_1

3. Ministry of Health RI. Indonesia Health Profile 2018. Jakarta: Catalog in Publication Indonesia Ministry of Health RI. 2019

4. Ranuhardy D, dan Sar RM. Ilmu Penyakit Dalam ed. VI. Jakarta Pusat: InternaPublishing. 2014

5. American Cancer Society. Key Statistics for Ovarian Cancer. 2017. URL https://cancerstatisticscenter.cancer.org/? ga $=2.230993302 .882924594 .1600401389$ 241747158.1592280546\#!/.

6. Pusat Data dan Informasi Kementerian Kesehatan RI. Situasi Penyakit Kanker. 2015. URL:https://pusdatin.kemkes.go.id/article/vie w/15090700004/situasi-penyakit-kanker.html

7. Berek JS, Abaid LN, Anderson JN, Aubuchon $\mathrm{M}$, Baker VN, Baram DA et al. Berek and Novaks Gynecology. USA: Lippincott Williams \& Wilkins. 2007.

8. Liwang F, Tanto C, Hanifat S, dan Pradipta EA. Kapita Selekta Kedokteran ed. IV. Jakarta: Media Aesculapius. 2014. 
9. Das PM, and Bast RC. Early Detection of Ovarian Cancer. Journal Biomarkers in Medicine. 2008; 2(3): 291-303

10. Simamora RPA, Hanriko R, Sari RDP. Hubungan Usia, Jumlah Paritas, dan Usia Menarche Terhadap Derajat Histopatologi Kanker Ovarium di RSUD Dr. H. Abdul Moeloek Bandar Lampung Tahun 2015-2016. Majority, 2018;(7)2:7-13

11. Vecchia CL. Ovarian Cancer: epidemiology and risk factors. European Journal of Cancer Prevention, 2017 Jan;26(1):55-62

12. Johari $A B$, Siregar $F G$. Insidensi Kanker Ovarium berdasarkan Faktor Risiko di RSUP Haji Adam Malik Tahun 2008-2011. E-Jurnal FK USU, 2013; 1 (1): 1-6

13. Rasmussen ELK, Hannibal CG, Dehlendorff C, Baandrup L, Junge J, Vang R, et al. Parity, infertility, oral contraceptives, and hormone replacement therapy and the risk of ovarian serous borderline tumors: A nationwide casecontrol study. Gynecologic Oncology Journal, 2017; 1(1), 6-11.

14. Stentz NC, Koelper NC, Sammel MD, Barnhart KT, Nicolais L, Senapati S, et al. Infertility Associated with Elevations in Ovarian Cancer Biomarkers in Later Fertility and Sterility. September 2017; 108(3):e212-e213. DOI: 10.1016/j.fertnstert.2017.07.628

15. Gea IT, Loho MF, Wagey FW. Gambaran jenis kanker ovarium di RSUP Prof. Dr. R.D. Kandou Manado Periode Januari 2013 Desember 2015. Jurnal e-Clinic, 2016; 4(2): 1-5. doi.org/10.35790/ecl.4.2.2016.14374

16. Ginting DB. Gambaran Faktor-faktor Risiko yang Berpengaruh pada Terjadinya Kanker Ovarium Tipe Epitelial di Poli Onkologi Ginekologi RSUD Dr. Soetomo Surabaya Periode Maret - April 2016. Tesis. Universitas Airlangga. 2016.

17. Yanti, Desi AM, Sulistianingsih A. Faktor Determinant Terjadinya Kanker Ovarium di Rumah Sakit Umum Daerah Abdoel Moelok Provinsi Lampung 2015. Ejournal UMM, 2016; 7 (2):79-87.

18. Lahmuddin T, Maulani H, Musa Z, dan Saleh I. Korelasi Antara Overekspresi p53 dengan Derajat Histopatologi dan Stadium Klinis Karsinoma Ovarium. Jurnal Kedokteran dan Kesehatan, Oktober 2015; 2 (3): 267-275 